九州大学学術情報リポジトリ

Kyushu University Institutional Repository

Some Chemical Properties of Soils from Two Agroecological Regions of Bangladesh : Region 5 : Lower Atrai Basin and Region 6 : Lower Purnabhaba Floodplain

Alam, S. M. Mahbubul

Moslehuddin, Abu Zofar Md.

Department of Soil Science, Bangladesh Agricultural University

Is lam, Md. Rafiqul

Department of Soil Science, Bangladesh Agricultural University

Egashira, Kazuhiko

Faculty of Agriculture, Kyushu University

https://doi.org/10.5109/9305

出版情報：九州大学大学院農学研究院紀要. 52 (1)，pp. 195-202，2007-02-28. Faculty of Agriculture, Kyushu University

バージョン :

権利関係 : 


\title{
Some Chemical Properties of Soils from Two Agroecological Regions of Bangladesh: Region 5 - Lower Atrai Basin and Region 6 - Lower Purnabhaba Floodplain
}

\section{S. M. Mahbubul ALAM ${ }^{1}$, Abu Zofar Md. MOSLEHUDDIN ${ }^{1}$, Md. Rafiqul ISLAM ${ }^{1}$ and Kazuhiko EGASHIRA*}

\author{
Laboratory of Soil Science, Division of Soil Science and Plant Production, \\ Department of Plant Resources, Faculty of Agriculture, \\ Kyushu University, Fukuoka 812-8581, Japan \\ (Received November 10, 2006 and accepted December 1, 2006)
}

\begin{abstract}
Bangladesh has been divided into 30 Agroecological Regions (AEZs) and the applied agricultural research has currently been conducted on this basis. An experiment was undertaken to elucidate chemical properties of fourteen soils collected from AEZ 5 of the Lower Atrai Basin and six soils from AEZ 6 of the Lower Purnabhaba Floodplain. The soils belonged to five soil series of Laskara, Tarash, Manda, Malanchi and Gangachara in AEZ 5 and one soil series of Jaonia in AEZ 6. Particle-size distribution, pH, active acidity, lime requirement, electrical conductivity (EC), organic carbon and total nitrogen, available sulfur and phosphorus, cation exchange capacity (CEC), exchangeable calcium, magnesium, sodium and potassium, and non-exchangeable potassium were determined following the standard methods.

Most of the soils from AEZ 5 were medium-textured (loam to silty loam) except the Tarash-1 and Tarash-2 soils which were in the same category as the soils from AEZ 6 of fine-texture (silty clay loam, silty clay and clay). The fineness of texture was related to the position of soils in the lower elevation and accumulation of clay. The latter group of the soils had, in general, higher values of organic matter, lime requirement, total nitrogen, $\mathrm{CEC}$, and some exchangeable cations. But, the values for $\mathrm{pH}, \mathrm{EC}$, available sulfur and phosphorus were not related to the difference between two groups of the soils. Soil test values were compared with the Bangladesh soil standards for crop requirement.
\end{abstract}

\section{INTRODUCTION}

Bangladesh is one of the greatest deltas of the world having a wider range and greater complexity of land. Population density is high and is increasing while the agricultural land is decreasing rapidly due to construction of homestead, factories, roads, highways, etc. As an agro-based country, Bangladesh needs to produce more crops to feed the ever-growing population. Proper management of soil is an important aspect to sustain its productivity. For research planning and better crop production, the basic data on physical and chemical properties of soils are important.

Physiographically the soils in Bangladesh are classified into three major units: Tertiary hills (12\%), Pleistocene terraces (8\%), and Holocene floodplains $(80 \%)$. Based on the mode of formation and morphological appearance, soils are grouped into 21 general soil types of the Bangladesh soil classification system, which have been correlated with USDA Soil Taxonomy and FAO-UNESCO soil classification system (Saheed, 1984).

Again, Bangladesh has been divided into 30 Agroecological Regions (popularly known as AEZs) based on physiography, inundation land types, soils, and agroclimate (FAO-UNDP, 1988). Agricultural research, and technology generation and transfer, etc. are now going on the AEZ basis. The present work was focused on the soils of the two AEZs of the Lower Atrai Basin (AEZ 5)

\footnotetext{
1 Department of Soil Science, Bangladesh Agricultural University, Mymensingh-2202, Bangladesh

* Corresponding author (E-mail: kegashi@agr.kyushu-u.ac.jp)
}

and the Lower Purnabhaba Floodplain (AEZ 6) which were not given due attention previously.

AEZ 5 of the Lower Atrai Basin comprises the low-lying area between the Barind Tract and Ganges River Floodplain. It includes the Chalan Bil area. Most of this region lies in Naogaon and Natore Districts. Small areas extend into Rajshahi, Bogra and Sirajgang Districts. Total area of this AEZ is $851 \mathrm{~km}^{2}$. Smooth, low-lying basin land occupies most of the region. Areas bordering the Ganges, Lower Atrai and Little Jamuna Floodplains have some ridges penetrating into the basin; and the relief is locally irregular near river channels. AEZ 6 of the Lower Purnabhaba Floodplain is located in the western part of Naogaon District and includes little areas of Chapainawabgonj Districts. Total area of this region is $129 \mathrm{~km}^{2}$ only. Basins and bils separated by low floodplain ridges occupy the whole area of this AEZ (FAO-UNDP, 1988).

The objective of the present study was to elucidate the physical and chemical properties of soils of these two AEZs in order to ascertain their potentiality for efficient use of the land resources, and better soil and crop management.

\section{MATERIALS AND METHODS}

\section{Soils used}

Major soil series of the AEZs under study were identified from the semi-detailed soil survey reports of different Upazilas covering the area. In AEZ 5, five soil series were found to occur: Laskara, Tarash, Manda, Malanchi, and Gangachara. Considering their extent of 
occurrence, 4 samples were collected from each of Tarash and Gangachara, 3 from Laskara, 2 from Manda, and 1 from Malanchi series. In AEZ 6, only one soil series (Jaonia) was found to occur. Six samples were collected from this AEZ considering the difference in location and land type. Thus, in total, twenty soil samples were collected from a depth of $0-15 \mathrm{~cm}$. General features of these soils are presented in Table 1. The soil samples were dried at room temperature, crushed, mixed thoroughly, sieved with a 2-mm sieve and preserved in plastic bags for subsequent laboratory analyses.

\section{Analytical procedures}

Particle-size analysis was carried out by the hydrometer method as outlined by Bouyoucos (1927). The textural classes were then determined by plotting the results on a triangular diagram designed by Marshall (1947) following the USDA system. The $\mathrm{pH}$ was determined by a glass-electrode $\mathrm{pH}$ meter in the soil suspension having a soil:water ratio of $1: 2.5$, after 30-min shaking. The electrical conductivity (EC) was measured by a EC meter in the soil suspension having a soil:water ratio of 1:5, after 30-min shaking.

To determine active acidity (exchangeable $\mathrm{Al}$ ), soil was extracted with $1 \mathrm{M} \mathrm{KCl}$. The filtrate was titrated against $0.01 \mathrm{M} \mathrm{NaOH}$ while stirring using phenolphthalein as an indicator. Lime requirement was calculated from this value. The lime requirement was also determined using the widely followed method given by

Table 1. General information of the soils

\begin{tabular}{|c|c|c|c|c|c|c|}
\hline AEZ & $\begin{array}{l}\text { Soil } \\
\text { series }\end{array}$ & $\begin{array}{l}\text { Land } \\
\text { type }^{1)}\end{array}$ & $\begin{array}{l}\text { Parent } \\
\text { material }\end{array}$ & $\begin{array}{l}\text { General soil } \\
\text { type }^{2)}\end{array}$ & Location & Crop \\
\hline \multirow{14}{*}{$\begin{array}{l}\text { Lower } \\
\text { Atrai } \\
\text { Basin }\end{array}$} & Laskara-1 & MHL & $\begin{array}{l}\text { Tista } \\
\text { alluvium }\end{array}$ & $\begin{array}{l}\text { Non-calcareous } \\
\text { Dark Grey } \\
\text { Floodplain Soil }\end{array}$ & $\begin{array}{l}\text { Singhradanra } \\
\text { Raninagor } \\
\text { Naogaon }\end{array}$ & $\begin{array}{l}\text { T. Aus, T. Aman, } \\
\text { mustard, sesame, } \\
\text { sesbania }\end{array}$ \\
\hline & Laskara-2 & MLL & $\begin{array}{l}\text { Tista } \\
\text { alluvium }\end{array}$ & $\begin{array}{l}\text { Non-calcareous } \\
\text { Dark Grey } \\
\text { Floodplain Soil }\end{array}$ & $\begin{array}{l}\text { Singhradanra } \\
\text { Raninagor } \\
\text { Naogaon }\end{array}$ & $\begin{array}{l}\text { Mixed Aus and } \\
\text { Deepwater Aman, } \\
\text { Boro }\end{array}$ \\
\hline & Laskara-3 & MHL & $\begin{array}{l}\text { Tista } \\
\text { alluvium }\end{array}$ & $\begin{array}{l}\text { Non-calcareous } \\
\text { Dark Grey } \\
\text { Floodplain Soil }\end{array}$ & $\begin{array}{l}\text { Kalikapur } \\
\text { Atrai } \\
\text { Naogaon }\end{array}$ & $\begin{array}{l}\text { T. Aus, T. Aman, } \\
\text { Boro, gram, }\end{array}$ \\
\hline & Tarash-1 & MHL & $\begin{array}{l}\text { Atrai } \\
\text { alluvium }\end{array}$ & $\begin{array}{l}\text { Non-calcareous } \\
\text { Dark Grey } \\
\text { Floodplain Soil }\end{array}$ & $\begin{array}{l}\text { Sinda } \\
\text { Raninagor } \\
\text { Naogaon }\end{array}$ & $\begin{array}{l}\text { T. Aus, T. Aman, } \\
\text { Boro, sesbania, }\end{array}$ \\
\hline & Tarash-2 & MLL & $\begin{array}{l}\text { Atrai } \\
\text { alluvium }\end{array}$ & $\begin{array}{l}\text { Non-calcareous } \\
\text { Dark Grey } \\
\text { Floodplain Soil }\end{array}$ & $\begin{array}{l}\text { Lohachora } \\
\text { Raninagor } \\
\text { Naogaon }\end{array}$ & $\begin{array}{l}\text { Mixed Aus and } \\
\text { Deepwater Aman, } \\
\text { Boro }\end{array}$ \\
\hline & Tarash-3 & MLL & $\begin{array}{l}\text { Atrai } \\
\text { alluvium }\end{array}$ & $\begin{array}{l}\text { Non-calcareous } \\
\text { Dark Grey } \\
\text { Floodplain Soil }\end{array}$ & $\begin{array}{l}\text { Kalikapur } \\
\text { Atrai } \\
\text { Naogaon }\end{array}$ & $\begin{array}{l}\text { Mixed Aus and } \\
\text { Deepwater Aman, } \\
\text { Boro }\end{array}$ \\
\hline & Tarash-4 & MLL & $\begin{array}{l}\text { Atrai } \\
\text { alluvium }\end{array}$ & $\begin{array}{l}\text { Non-calcareous } \\
\text { Dark Grey } \\
\text { Floodplain Soil }\end{array}$ & $\begin{array}{l}\text { Ahsangonj } \\
\text { Atrai } \\
\text { Naogaon }\end{array}$ & $\begin{array}{l}\text { Mixed Aus and } \\
\text { Deepwater Aman, } \\
\text { Boro }\end{array}$ \\
\hline & Manda-1 & $\mathrm{HL}$ & $\begin{array}{l}\text { Tista } \\
\text { alluvium }\end{array}$ & $\begin{array}{l}\text { Non-calcareous } \\
\text { Dark Grey } \\
\text { Floodplain Soil }\end{array}$ & $\begin{array}{l}\text { Akdala } \\
\text { Hapinia } \\
\text { Naogaon }\end{array}$ & $\begin{array}{l}\text { Aus, Aman, Boro, } \\
\text { jute, wheat, potato, } \\
\text { sweet potato, maize, } \\
\text { brinjal, vegetables }\end{array}$ \\
\hline & Manda-2 & $\mathrm{HL}$ & $\begin{array}{l}\text { Tista } \\
\text { alluvium }\end{array}$ & $\begin{array}{l}\text { Non-calcareous } \\
\text { Dark Grey } \\
\text { Floodplain Soil }\end{array}$ & $\begin{array}{l}\text { Chackbilaki } \\
\text { Raninagor } \\
\text { Naogaon }\end{array}$ & $\begin{array}{l}\text { Aus, Aman, Boro, } \\
\text { jute, wheat, potato, } \\
\text { sweet potato, maize, } \\
\text { brinjal, vegetables }\end{array}$ \\
\hline & Malanchi & $\mathrm{HL}$ & $\begin{array}{l}\text { Tista } \\
\text { alluvium }\end{array}$ & $\begin{array}{l}\text { Non-calcareous } \\
\text { Dark Grey } \\
\text { Floodplain Soil }\end{array}$ & $\begin{array}{l}\text { Hapania } \\
\text { Naogaon }\end{array}$ & $\begin{array}{l}\text { Aus, Aman, Boro, } \\
\text { jute, wheat, potato, } \\
\text { sweet potato, maize, } \\
\text { brinjal, vegetables }\end{array}$ \\
\hline & Gangachara-1 & $\mathrm{HL}$ & $\begin{array}{l}\text { Tista } \\
\text { alluvium }\end{array}$ & $\begin{array}{l}\text { Non-calcareous } \\
\text { Dark Grey } \\
\text { Floodplain Soil }\end{array}$ & $\begin{array}{l}\text { Hapania } \\
\text { Naogaon }\end{array}$ & $\begin{array}{l}\text { Aus, Aman, Boro, } \\
\text { wheat, cotton, } \\
\text { vegetables, fruits }\end{array}$ \\
\hline & Gangachara-2 & MHL & $\begin{array}{l}\text { Tista } \\
\text { alluvium }\end{array}$ & $\begin{array}{l}\text { Non-calcareous } \\
\text { Dark Grey } \\
\text { Floodplain Soil }\end{array}$ & $\begin{array}{l}\text { Chackbilaki } \\
\text { Raninagor } \\
\text { Naogaon }\end{array}$ & $\begin{array}{l}\text { Aus, Aman, Boro, } \\
\text { wheat, cotton, } \\
\text { vegetables, fruits }\end{array}$ \\
\hline & Gangachara-3 & $\mathrm{HL}$ & $\begin{array}{l}\text { Tista } \\
\text { alluvium }\end{array}$ & $\begin{array}{l}\text { Non-calcareous } \\
\text { Dark Grey } \\
\text { Floodplain Soil }\end{array}$ & $\begin{array}{l}\text { Ahsangonj } \\
\text { Atrai } \\
\text { Naogaon }\end{array}$ & $\begin{array}{l}\text { Aus, Aman, Boro, } \\
\text { wheat, cotton }\end{array}$ \\
\hline & Gangachara-4 & MHL & $\begin{array}{l}\text { Tista } \\
\text { alluvium }\end{array}$ & $\begin{array}{l}\text { Non-calcareous } \\
\text { Dark Grey } \\
\text { Floodplain Soil }\end{array}$ & $\begin{array}{l}\text { Ahsangonj } \\
\text { Atrai } \\
\text { Naogaon }\end{array}$ & $\begin{array}{l}\text { Aus, Aman, Boro, } \\
\text { wheat, sunflower, } \\
\text { gram, lentil, onion, } \\
\text { tomato, vegetables, } \\
\text { fruits }\end{array}$ \\
\hline
\end{tabular}


Table 1. General information of the soils (contd)

\begin{tabular}{|c|c|c|c|c|c|c|}
\hline AEZ & $\begin{array}{l}\text { Soil } \\
\text { series }\end{array}$ & $\begin{array}{l}\text { Land } \\
\text { type }^{1)}\end{array}$ & $\begin{array}{l}\text { Parent } \\
\text { material }\end{array}$ & $\begin{array}{l}\text { General soil } \\
\text { type }^{2)}\end{array}$ & Location & Crop \\
\hline \multirow{6}{*}{$\begin{array}{l}\text { Lower } \\
\text { Purnabhaba } \\
\text { Floodplain }\end{array}$} & Jaonia-1 & $\mathrm{LL}$ & $\begin{array}{l}\text { Purnabhaba } \\
\text { alluvium }\end{array}$ & Acid Basin Clay & $\begin{array}{l}\text { Radhanagor } \\
\text { Gomostapur } \\
\text { Chapainawabgonj }\end{array}$ & $\begin{array}{l}\text { Deepwater Aman, } \\
\text { Boro, khesari }\end{array}$ \\
\hline & Jaonia-2 & MLL & $\begin{array}{l}\text { Purnabhaba } \\
\text { alluvium }\end{array}$ & Acid Basin Clay & $\begin{array}{l}\text { Radhanagor } \\
\text { Gomostapur } \\
\text { Chapainawabgonj }\end{array}$ & $\begin{array}{l}\text { Deepwater Aman, } \\
\text { Boro, khesari }\end{array}$ \\
\hline & Jaonia-3 & $\mathrm{LL}$ & $\begin{array}{l}\text { Purnabhaba } \\
\text { alluvium }\end{array}$ & Acid Basin Clay & $\begin{array}{l}\text { Nitpur } \\
\text { Porsa } \\
\text { Naogaon }\end{array}$ & $\begin{array}{l}\text { Deepwater Aman, } \\
\text { Boro, khesari }\end{array}$ \\
\hline & Jaonia-4 & MLL & $\begin{array}{l}\text { Purnabhaba } \\
\text { alluvium }\end{array}$ & Acid Basin Clay & $\begin{array}{l}\text { Nitpur } \\
\text { Porsa } \\
\text { Naogaon }\end{array}$ & $\begin{array}{l}\text { Deepwater Aman, } \\
\text { Boro, khesari }\end{array}$ \\
\hline & Jaonia-5 & $\mathrm{LL}$ & $\begin{array}{l}\text { Purnabhaba } \\
\text { alluvium }\end{array}$ & Acid Basin Clay & $\begin{array}{l}\text { Aihai } \\
\text { Sapahar } \\
\text { Naogaon }\end{array}$ & $\begin{array}{l}\text { Deepwater Aman, } \\
\text { Boro, khesari }\end{array}$ \\
\hline & Jaonia-6 & MLL & $\begin{array}{l}\text { Purnabhaba } \\
\text { alluvium }\end{array}$ & Acid Basin Clay & $\begin{array}{l}\text { Aihai } \\
\text { Sapahar } \\
\text { Naogaon }\end{array}$ & $\begin{array}{l}\text { Deepwater Aman, } \\
\text { Boro, khesari }\end{array}$ \\
\hline
\end{tabular}

\footnotetext{
${ }^{1)}$ Land type: HL, highland; MHL, medium highland; MLL, medium lowland; LL, lowland. HL: land which is above the normal flood level; MHL, MLL and LL: land which is normally flooded up to a depth of about $90 \mathrm{~cm}, 90-180 \mathrm{~cm}$ deep and 180-270 cm deep, respectively, during the monsoon season.

${ }^{2}$ Soil classification based on the Bangladesh system.

${ }^{3)}$ Scientific name is Lathyrus sarivum.
}

Shoemaker et al. (1961). In this method, soil, water and an extracting buffer solution were mixed in 1:1:2 ratio. They were stirred for 15 minutes and the $\mathrm{pH}$ of the suspension was measured with a $\mathrm{pH}$ meter. The amount of lime required against the measured $\mathrm{pH}$ value was found out from a correlation table for increasing the soil $\mathrm{pH}$ to a desired level.

The organic carbon content was determined by the wet oxidation method as outlined by Nelson et al. (1982) and the organic matter content was calculated by multiplying the organic carbon content with a conventional factor of 1.724 .

The total nitrogen content was determined by the micro-Kjeldahl digestion method. Digestion was made with concentrated $\mathrm{H}_{2} \mathrm{SO}_{4}$ with addition of catalyst mixture $\left(\mathrm{K}_{2} \mathrm{SO}_{4}\right.$ : $\mathrm{CuSO}_{4} \cdot 5 \mathrm{H}_{2} \mathrm{O}$ :Se in the ratio of 10:1:0.1). Nitrogen in the digest was estimated by distillation with $40 \% \mathrm{NaOH}$ followed by titration of the distillate trapped in the $\mathrm{H}_{3} \mathrm{BO}_{3}$ solution against $0.005 \mathrm{M} \mathrm{H}_{2} \mathrm{SO}_{4}$ (Bremner and Mulvaney, 1982). The available sulfur content was determined by the calcium chloride $(0.15 \%)$ extraction method (Williams and Steinbergs, 1959). The available phosphorus content was determined by the two different methods as given by Olsen et al. (1954) and Bray and Kurtz (1945).

Cation exchange capacity (CEC) was determined by the sodium saturation method as described by Chapman (1965). Exchangeable calcium, sodium and potassium were extracted from soil using $1 \mathrm{M} \mathrm{CH}_{3} \mathrm{COONH}_{4}$ and their concentrations in the extract were directly determined by a flame photometer. In addition, the non-exchangeable potassium content was determined by the boiling $\mathrm{HNO}_{3}$ method (Knudsen et al., 1982). Exchangeable magnesium was extracted by DTPA solution and its concentration in the extract was determined directly by an atomic absorption spectrophotometer (AAS)

\section{RESULTS AND DISCUSSION}

\section{Particle-size distribution}

Data on the particle-size distribution and the USDA textural class of the soils presented in Table 2 indicated that the contents of sand, silt and clay varied widely with soil series and also with samples in the same soil series. The soils collected from AEZ 5 of the Lower Atrai Basin was mostly medium-textured (loam and silt loam) except the Tarash-1 and Tarash-2 soils which were identified as silty clay loam and silty clay, respectively. On the other hand, all six soils from AEZ 6 of the Lower Purnabhaba Floodplain were fine-textured (clay and silty clay).

On the basis of the clay content, the soils collected from AEZ 5 could be grouped into three: high ( $>40 \%)$ in the Tarash-1 and Tarash-2 soils, medium (20-40\%) in the soils of the Malanchi and Laskara series and low $(<20 \%)$ in the other soils. While, the soils of AEZ 6 contained high to very high amounts of clay (44-68\%). The higher clay contents were mostly related to the position of soils on the lower topography where clay has been deposited through run-off water over the time.

It appears from the results in Table 2 that the silt content had higher values for most of the soils especially from AEZ 5. Soils like silt loam and clay loam textures have higher agricultural values being less susceptible to becoming loose and open (Weir, 1989). The soil having the silt loam texture can easily be kept in a state good for tilth, favourable for germination of seeds and easy for 
Table 2. Particle-size distribution and texture of the soils

\begin{tabular}{|c|c|c|c|c|c|}
\hline \multirow{2}{*}{ AEZ } & \multirow{2}{*}{ Soil series } & \multicolumn{3}{|c|}{ Particle-size distribution (\%) } & \multirow{2}{*}{ Texture } \\
\hline & & Sand & Silt & Clay & \\
\hline \multirow{14}{*}{$\begin{array}{l}\text { Lower } \\
\text { Atrai } \\
\text { Basin }\end{array}$} & Laskara-1 & 42 & 34 & 24 & loam \\
\hline & Laskara-2 & 36 & 36 & 28 & loam \\
\hline & Laskara-3 & 14 & 66 & 20 & silt loam \\
\hline & Tarash-1 & 22 & 34 & 44 & silty clay loam \\
\hline & Tarash-2 & 20 & 30 & 50 & silty clay \\
\hline & Tarash-3 & 24 & 60 & 16 & silt loam \\
\hline & Tarash-4 & 32 & 54 & 14 & silt loam \\
\hline & Manda-1 & 40 & 50 & 10 & silt loam \\
\hline & Manda-2 & 36 & 56 & 8 & silt loam \\
\hline & Malanchi & 16 & 62 & 22 & silt loam \\
\hline & Gangachara-1 & 20 & 66 & 14 & silt loam \\
\hline & Gangachara-2 & 22 & 70 & 8 & silt loam \\
\hline & Gangachara-3 & 22 & 64 & 14 & silt loam \\
\hline & Gangachara-4 & 24 & 66 & 10 & silt loam \\
\hline \multirow{6}{*}{$\begin{array}{l}\text { Lower } \\
\text { Purnabhaba } \\
\text { Floodplain }\end{array}$} & Jaonia-1 & 16 & 20 & 64 & clay \\
\hline & Jaonia-2 & 26 & 30 & 44 & silty clay \\
\hline & Jaonia-3 & 16 & 16 & 68 & clay \\
\hline & Jaonia-4 & 18 & 20 & 62 & clay \\
\hline & Jaonia-5 & 16 & 34 & 50 & silty clay \\
\hline & Jaonia-6 & 14 & 28 & 58 & silty clay \\
\hline
\end{tabular}

root penetration, and has the considerable water-holding capacity. The silt loam soil may be highly productive if managed properly. On the other hand, higher clay gives the soil higher fertility condition with the good water-retention capacity which is congenial for transplanted rice cultivation.

\section{Soil reaction $(\mathbf{p H})$}

Data on the soil pH are presented in Table 3. The $\mathrm{pH}$ of the soils from AEZ 5 ranged from 5.2 to 6.1 , i. e. the soils were slightly acidic to acidic in reaction. The $\mathrm{pH}$ range of the soils from AEZ 6 was in between 4.8 and
5.2 which were mostly acidic in nature. For some crops the soil reaction could be a problem as Tamhane et al. (1970) reported that the most soil nutrients were available to plants in a $\mathrm{pH}$ range from 6.5 to 7.5 . So, $\mathrm{pH}$ should be kept between 6.5 and 7.5 by the soil and crop managements including application of lime.

\section{Active acidity}

The values of active acidity of the soils, which is equivalent to the amount of exchangeable aluminum adsorbed on colloids, were found in a narrow range between 0.2 and $0.5 \mathrm{cmol}_{\mathrm{c}} \mathrm{kg}^{-1}$ (Table 3 ). The active

Table 3. Soil $\mathrm{pH}$, active acidity and lime requirement of the soils

\begin{tabular}{|c|c|c|c|c|c|}
\hline \multirow{2}{*}{ AEZ } & \multirow{2}{*}{ Soil series } & \multirow{2}{*}{$\mathrm{pH}$} & \multirow{2}{*}{$\begin{array}{c}\text { Active } \\
\text { acidity } \\
\left(\mathrm{cmol}_{\mathrm{c}} \mathrm{kg}^{-1}\right)\end{array}$} & \multicolumn{2}{|c|}{$\begin{array}{c}\text { Lime requirement }\left(\mathrm{t} \mathrm{ha}^{-1}\right) \text { on } \\
\text { the basis of }\end{array}$} \\
\hline & & & & Active acidity & $\begin{array}{l}\text { Shoemaker } \\
\text { method }\end{array}$ \\
\hline \multirow{14}{*}{$\begin{array}{l}\text { Lower } \\
\text { Atrai } \\
\text { Basin }\end{array}$} & Laskara-1 & 5.2 & 0.4 & 0.89 & 4.62 \\
\hline & Laskara-2 & 5.5 & 0.3 & 0.67 & 4.62 \\
\hline & Laskara-3 & 5.4 & 0.3 & 0.67 & 6.07 \\
\hline & Tarash-1 & 5.9 & 0.2 & 0.45 & 7.51 \\
\hline & Tarash-2 & 5.5 & 0.3 & 0.67 & 11.6 \\
\hline & Tarash-3 & 5.9 & 0.3 & 0.67 & 3.40 \\
\hline & Tarash-4 & 5.5 & 0.2 & 0.45 & 6.07 \\
\hline & Manda-1 & 5.3 & 0.3 & 0.67 & 4.62 \\
\hline & Manda-2 & 5.3 & 0.3 & 0.67 & 3.40 \\
\hline & Malanchi & 6.0 & 0.2 & 0.45 & 7.53 \\
\hline & Gangachara-1 & 5.5 & 0.3 & 0.67 & 6.07 \\
\hline & Gangachara-2 & 6.1 & 0.2 & 0.45 & 0.00 \\
\hline & Gangachara-3 & 5.7 & 0.2 & 0.45 & 3.40 \\
\hline & Gangachara-4 & 5.8 & 0.3 & 0.67 & 3.40 \\
\hline \multirow{6}{*}{$\begin{array}{l}\text { Lower } \\
\text { Purnabhaba } \\
\text { Floodplain }\end{array}$} & Jaonia-1 & 5.2 & 0.4 & 0.89 & 18.7 \\
\hline & Jaonia-2 & 4.8 & 0.5 & 1.13 & 17.3 \\
\hline & Jaonia-3 & 4.9 & 0.4 & 0.89 & 28.7 \\
\hline & Jaonia-4 & 4.9 & 0.4 & 0.89 & 27.2 \\
\hline & Jaonia-5 & 5.1 & 0.3 & 0.67 & 14.6 \\
\hline & Jaonia-6 & 5.2 & 0.3 & 0.67 & 13.1 \\
\hline
\end{tabular}


acidity of the soils from AEZ 5 was mostly 0.2 or $0.3 \mathrm{cmol}_{\mathrm{c}} \mathrm{kg}^{-1}$, except the Laskara-1 soil $\left(0.4 \mathrm{cmol}_{\mathrm{c}} \mathrm{kg}^{-1}\right)$, whereas the soils from AEZ 6 had values from 0.3 to $0.5 \mathrm{cmol}_{\mathrm{c}} \mathrm{kg}^{-1}$. It was observed that soils having the lower $\mathrm{pH}$ values had the higher active acidity values. From the correlation matrix (Table 7) it was found that active acidity was significantly correlated with CEC.

\section{Lime requirement}

As the soils were found to be mostly acidic in reaction, lime requirement was estimated using two different methods. According to the estimate based on the active acidity values, the soils of AEZ 5 required lime $\left(\mathrm{CaCO}_{3}\right)$ at the rate of 0.45 or $0.67 \mathrm{t} \mathrm{ha}{ }^{-1}$, except the Laskara-1 soil that required the amount of $0.89 \mathrm{t} \mathrm{ha}^{-1}$. The six soils of AEZ 6 required somewhat higher amounts of lime ranging from 0.67 to $1.13 \mathrm{t} \mathrm{ha-1}$ (Table 3).

According to the Shoemaker method, the lime requirement of the soils from AEZ 5 was as follows: ranging from 4.62 to $6.07 \mathrm{t} \mathrm{ha}^{-1}$ for the Laskara series; 3.40 to 11.6 tha $^{-1}$ for the Tarash series; 3.40 to $4.62 \mathrm{t} \mathrm{ha}^{-1}$ for the Manda series; $7.53 \mathrm{t} \mathrm{ha}^{-1}$ for the Malanchi series; and 0.00 to $6.07 \mathrm{t} \mathrm{ha}^{-1}$ for the Gangachara series. While, lime requirement of the Jaonia series of AEZ 6 ranged from 13.1 to $28.7 \mathrm{t} \mathrm{ha}^{-1}$, which was much higher than that for the soils of AEZ 5.

The above results indicated that the two methods were greatly different in the lime requirement of the soils and that the estimates by the Shoemaker method were much higher than the estimates based on the active acidity.

\section{Electrical conductivity}

Data on the electrical conductivity are presented in
Table 4. The values ranged from 0.03 to $0.08 \mathrm{dS} \mathrm{m}^{-1}$ in the AEZ 5 soils and from 0.03 to $0.06 \mathrm{dS} \mathrm{m}^{-1}$ in the AEZ 6 soils and indicated non-saline nature of these soils. No significant difference was observed among the soils of the two AEZs or among the soils of the same soil series.

\section{Organic matter content}

The organic matter content of the AEZ 5 soils ranged from 10.9 to $24.2 \mathrm{~g} \mathrm{~kg}^{-1}$ while that of the AEZ 6 soils ranged from 16.8 to $25.2 \mathrm{~g} \mathrm{~kg}^{-1}$ (Table 4). The soils having the high to very high clay contents mostly had the organic matter content around or more than $20 \mathrm{~g}$ $\mathrm{kg}^{-1}$. According to the grading of BARC (1997) the organic matter content of these soils was evaluated to be mostly in the medium level. The values were above the usually very low levels of the organic matter content, mainly due to the lower topographic position of the soils. From the correlation matrix (Table 7) it was found that the organic matter content was significantly correlated with the clay and total nitrogen contents, CEC, and the exchangeable calcium and magnesium contents.

\section{Total nitrogen content}

The total nitrogen content of the soils from AEZ 5 varied from 0.8 to $1.4 \mathrm{~g} \mathrm{~kg}^{-1}$ while that of the AEZ 6 soils had the higher contents of 1.3 to $1.5 \mathrm{~g} \mathrm{~kg}^{-1}$. The total nitrogen content of the soils from AEZ 5 was evaluated to be in the low to very low level while that of the soils from AEZ 6 to be in the low level according to the grading of BARC (1997). Portch and Islam (1984) also found that $100 \%$ of the soils studied were deficient in available nitrogen, which was similar to the present findings. The total nitrogen content was found to be significantly correlated with the clay and organic matter contents and CEC of the soils (Table 7).

Table 4. Electrical conductivity, organic matter and total nitrogen contents, and $\mathrm{C} / \mathrm{N}$ ratio of the soils

\begin{tabular}{|c|c|c|c|c|c|}
\hline AEZ & Soil series & $\begin{array}{c}\text { Electrical } \\
\text { conductivity } \\
\left(\mathrm{dS} \mathrm{m} \mathrm{m}^{-1}\right)\end{array}$ & $\begin{array}{l}\text { Organic } \\
\text { matter } \\
\left(\mathrm{g} \mathrm{kg}^{-1}\right)\end{array}$ & $\begin{array}{c}\text { Total } \\
\text { nitrogen } \\
\left(\mathrm{g} \mathrm{kg}^{-1}\right)\end{array}$ & $\begin{array}{l}\mathrm{C} / \mathrm{N} \\
\text { ratio }\end{array}$ \\
\hline \multirow{14}{*}{$\begin{array}{l}\text { Lower } \\
\text { Atrai } \\
\text { Basin }\end{array}$} & Laskara-1 & 0.08 & 14.9 & 0.8 & 10.2 \\
\hline & Laskara-2 & 0.04 & 18.7 & 1.2 & 9.2 \\
\hline & Laskara-3 & 0.07 & 18.3 & 1.4 & 7.6 \\
\hline & Tarash-1 & 0.06 & 23.7 & 1.1 & 12.2 \\
\hline & Tarash-2 & 0.06 & 24.2 & 1.4 & 10.0 \\
\hline & Tarash-3 & 0.07 & 12.6 & 0.7 & 10.0 \\
\hline & Tarash-4 & 0.04 & 14.7 & 0.7 & 12.8 \\
\hline & Manda-1 & 0.03 & 17.5 & 1.4 & 7.2 \\
\hline & Manda-2 & 0.03 & 10.9 & 0.8 & 8.1 \\
\hline & Malanchi & 0.05 & 19.2 & 0.8 & 13.2 \\
\hline & Gangachara-1 & 0.04 & 17.5 & 1.0 & 10.6 \\
\hline & Gangachara-2 & 0.07 & 15.2 & 1.0 & 9.3 \\
\hline & Gangachara-3 & 0.04 & 18.5 & 0.8 & 12.7 \\
\hline & Gangachara-4 & 0.06 & 22.8 & 1.0 & 13.9 \\
\hline \multirow{6}{*}{$\begin{array}{l}\text { Lower } \\
\text { Purnabhaba } \\
\text { Floodplain }\end{array}$} & Jaonia-1 & 0.04 & 21.3 & 1.3 & 9.5 \\
\hline & Jaonia-2 & 0.06 & 19.0 & 1.4 & 7.9 \\
\hline & Jaonia-3 & 0.03 & 25.2 & 1.5 & 9.7 \\
\hline & Jaonia-4 & 0.04 & 21.4 & 1.3 & 9.6 \\
\hline & Jaonia-5 & 0.06 & 23.2 & 1.3 & 10.0 \\
\hline & Jaonia-6 & 0.04 & 16.8 & 1.3 & 7.5 \\
\hline
\end{tabular}




\section{C/N ratio}

The $\mathrm{C} / \mathrm{N}$ ratio of the soils ranged from 7.2 to 13.9 with an average of 10.0 (Table 4). Brady (2002) stated that the $\mathrm{C} / \mathrm{N}$ ratio in agricultural top soils varied from 8.1 to 15.1. Most of the soils in the present study were found to have the $\mathrm{C} / \mathrm{N}$ ratio within this range.

\section{Available sulfur content}

The available sulfur content of the different soil series of AEZ 5 ranged from 16.3 to $32.6 \mathrm{mg} \mathrm{kg}^{-1}$ while that of the soils of AEZ 6 ranged from 12.9 to $198 \mathrm{mg} \mathrm{kg}^{-1}$ (Table 5). The Jaonia-3, Jaonia-4 and Jaonia-6 soils contained very high amounts of available sulfur, and in the other soils the available sulfur content was evaluated to be in a low to optimum range for crop production (BARC, 1997). The higher amount of available sulfur could be resulted from oxidation of sulfides during air-drying of the samples.

\section{Available phosphorus content}

The available phosphorus contents of the six soil series estimated by the Olsen and Bray \& Kurtz methods are shown in Table 5. According to the Olsen method the available phosphorus content ranged from 5.0 to $57.0 \mathrm{mg} \mathrm{kg}^{-1}$ for the soils of AEZ 5 and from 6.5 to $8.6 \mathrm{mg}$ $\mathrm{kg}^{-1}$ for the AEZ 6 soils. The available phosphorus contents of the soils were of the low level in all locations for the Jaonia series, and varied from medium to optimum levels for the Laskara series, from very low to high levels for the Tarash series, from low to optimum levels for the Manda series and from low to optimum levels for the Gangachara series, and it was observed to be in the high level for the soil of the Malanchi series (BARC, 1997). In the Bray \& Kurtz method, it was found that the contents of available phosphorus were higher than those by the Olsen method in the most cases. Both results were significantly correlated with each other (Table 7).

\section{Cation exchange capacity (CEC)}

The CEC of the soils of the six soil series was as follows: 20.4 to $21.9 \mathrm{cmol}_{\mathrm{c}} \mathrm{kg}^{-1}$ for the Laskara series, 15.4 to $28.4 \mathrm{cmol}_{\mathrm{c}} \mathrm{kg}^{-1}$ for the Tarash series, 10.9 to $12.4 \mathrm{cmol}_{\mathrm{c}}$ $\mathrm{kg}^{-1}$ for the Manda series, $12.4 \mathrm{cmol}_{\mathrm{c}} \mathrm{kg}^{-1}$ for the Malanchi series, 16.4 to $20.4 \mathrm{cmol}_{\mathrm{c}} \mathrm{kg}^{-1}$ for the Gangachara series and 26.8 to $31.3 \mathrm{cmol}_{\mathrm{c}} \mathrm{kg}^{-1}$ for the Jaonia series (Table $6)$. The CEC was estimated in the high level for the soils of the Tarash, Gangachara and Laskara series, in the medium level for the soils of the Manda and Malanchi series and in the high to very high level for the soils of the Jaonia series (BARC, 1997). The higher CEC values denote the comparatively high chemical activity of a soil, and it was found that the CEC was significantly correlated with active acidity and the contents of clay, organic matter, total nitrogen, and exchangeable calcium, magnesium and potassium in the present study (Table 7).

\section{Exchangeable calcium content}

The exchangeable calcium contents of the soils of the six different soil series of AEZ 5 and AEZ 6 are presented in Table 6. It was observed that the exchangeable calcium content for the Laskara, Tarash, Manda, Malanchi, and Gangachara series of AEZ 5 varied from 4.50 to $9.00,5.50$ to $14.8,1.94$ to $2.20,3.50$, and 2.50 to $3.26 \mathrm{cmol}_{\mathrm{c}} \mathrm{kg}^{-1}$, respectively, while that for the Jaonia series of AEZ 6 varied from 12.7 to $14.0 \mathrm{cmol}_{\mathrm{c}} \mathrm{kg}^{-1}$. The exchangeable calcium content was found to be in the very high level in all locations for the Jaonia series; it was to be in the medium to very high level for the Laskara series, the optimum to very high level for the Tarash series, the low level for the Manda series, the

Table 5. Available sulfur and phosphorus contents of the soils

\begin{tabular}{|c|c|c|c|c|}
\hline \multirow[b]{2}{*}{ AEZ } & \multirow[b]{2}{*}{ Soil series } & \multirow{2}{*}{$\begin{array}{l}\text { Available sulfur } \\
\quad\left(\mathrm{mg} \mathrm{kg}^{-1}\right)\end{array}$} & \multicolumn{2}{|c|}{ Available phosphorus (mg kg-1) } \\
\hline & & & Olsen method & $\begin{array}{c}\text { Bray and Kurtz } \\
\text { method }\end{array}$ \\
\hline \multirow{14}{*}{$\begin{array}{l}\text { Lower } \\
\text { Atrai } \\
\text { Basin }\end{array}$} & Laskara-1 & 32.6 & 9.2 & 12.5 \\
\hline & Laskara-2 & 18.8 & 9.1 & 14.5 \\
\hline & Laskara-3 & 22.8 & 18.9 & 13.5 \\
\hline & Tarash-1 & 18.4 & 6.3 & 7.6 \\
\hline & Tarash-2 & 18.0 & 5.0 & 7.9 \\
\hline & Tarash-3 & 17.6 & 24.9 & 19.5 \\
\hline & Tarash-4 & 18.1 & 21.9 & 20.2 \\
\hline & Manda-1 & 16.3 & 22.9 & 22.8 \\
\hline & Manda-2 & 17.9 & 6.5 & 10.1 \\
\hline & Malanchi & 17.5 & 24.2 & 20.7 \\
\hline & Gangachara-1 & 16.8 & 27.8 & 27.9 \\
\hline & Gangachara-2 & 17.8 & 57.0 & 40.2 \\
\hline & Gangachara-3 & 31.8 & 18.8 & 18.3 \\
\hline & Gangachara-4 & 20.9 & 15.8 & 17.9 \\
\hline \multirow{6}{*}{$\begin{array}{l}\text { Lower } \\
\text { Purnabhaba } \\
\text { Floodplain }\end{array}$} & Jaonia-1 & 13.5 & 7.4 & 7.9 \\
\hline & Jaonia-2 & 12.9 & 7.4 & 10.2 \\
\hline & Jaonia-3 & 156 & 7.7 & 10.7 \\
\hline & Jaonia-4 & 176 & 6.5 & 9.9 \\
\hline & Jaonia-5 & 34.3 & 8.6 & 10.6 \\
\hline & Jaonia-6 & 198 & 7.7 & 9.3 \\
\hline
\end{tabular}


Table 6. Cation exchange capacity (CEC), and exchangeable calcium, magnesium, potassium and sodium, and non-exchangeable potassium contents of the soils

\begin{tabular}{|c|c|c|c|c|c|c|c|}
\hline \multirow{3}{*}{ AEZ } & \multirow{3}{*}{ Soil series } & \multirow{2}{*}{ CEC } & \multicolumn{4}{|c|}{ Exchangeable } & \multirow{2}{*}{$\frac{\text { Non-exchangeable }}{\mathrm{K}}$} \\
\hline & & & $\mathrm{Ca}$ & $\mathrm{Mg}$ & $\mathrm{K}$ & $\mathrm{Na}$ & \\
\hline & & \multicolumn{6}{|c|}{$\left(\mathrm{cmol}_{\mathrm{c}} \mathrm{kg}^{-1}\right)$} \\
\hline \multirow{14}{*}{$\begin{array}{l}\text { Lower } \\
\text { Atrai } \\
\text { Basin }\end{array}$} & Laskara-1 & 20.9 & 4.50 & 5.46 & 0.27 & 0.55 & 4.5 \\
\hline & Laskara-2 & 21.9 & 9.00 & 6.92 & 0.19 & 0.74 & 5.9 \\
\hline & Laskara-3 & 20.4 & 6.24 & 6.04 & 0.24 & 0.62 & 7.0 \\
\hline & Tarash-1 & 24.4 & 14.8 & 7.80 & 0.18 & 0.68 & 4.6 \\
\hline & Tarash-2 & 28.4 & 13.0 & 8.20 & 0.27 & 0.74 & 4.9 \\
\hline & Tarash-3 & 15.4 & 7.50 & 7.32 & 0.22 & 0.49 & 7.5 \\
\hline & Tarash-4 & 16.4 & 5.50 & 4.66 & 0.14 & 0.49 & 5.7 \\
\hline & Manda-1 & 10.9 & 2.20 & 3.78 & 0.10 & 0.43 & 5.4 \\
\hline & Manda-2 & 12.4 & 1.94 & 2.92 & 0.07 & 0.31 & 5.0 \\
\hline & Malanchi & 12.4 & 3.50 & 5.78 & 0.10 & 0.87 & 6.2 \\
\hline & Gangachara-1 & 16.9 & 2.50 & 9.24 & 0.10 & 0.49 & 7.5 \\
\hline & Gangachara-2 & 16.4 & 3.26 & 7.06 & 0.08 & 0.68 & 7.7 \\
\hline & Gangachara-3 & 19.4 & 2.70 & 5.52 & 0.11 & 0.62 & 6.4 \\
\hline & Gangachara-4 & 20.4 & 3.04 & 6.16 & 0.08 & 0.55 & 6.1 \\
\hline \multirow{6}{*}{$\begin{array}{l}\text { Lower } \\
\text { Purnabhaba } \\
\text { Floodplain }\end{array}$} & Jaonia-1 & 26.8 & 14.0 & 8.80 & 0.44 & 0.62 & 3.5 \\
\hline & Jaonia-2 & 29.3 & 13.7 & 8.46 & 0.46 & 0.68 & 5.7 \\
\hline & Jaonia-3 & 30.3 & 12.7 & 9.24 & 0.36 & 0.68 & 7.8 \\
\hline & Jaonia-4 & 31.3 & 13.5 & 8.90 & 0.33 & 0.56 & 6.4 \\
\hline & Jaonia-5 & 28.3 & 14.0 & 8.70 & 0.50 & 0.56 & 7.5 \\
\hline & Jaonia-6 & 28.2 & 13.7 & 8.34 & 0.48 & 0.68 & 3.3 \\
\hline
\end{tabular}

medium level for the Malanchi series, and the low to medium level for the Gangachara series (BARC, 1997). From the correlation matrix (Table 7) it was found that the exchangeable calcium content was significantly correlated with the clay content, CEC, and the exchangeable magnesium and potassium contents.

\section{Exchangeable magnesium content}

Like the exchangeable calcium content, the exchangeable magnesium content of the soils of the two AEZs was in the very satisfactory level (Table 6). In general, the soils of AEZ 6 had higher amounts of exchangeable magnesium than did the most AEZ 5 soils. Variation of the exchangeable magnesium content was mainly due to the clay content and CEC of the soils, although the significant correlation was also observed with the organic matter, total nitrogen, and exchange- able calcium and potassium contents (Table 7).

\section{Exchangeable sodium content}

The exchangeable sodium content of the AEZ 5 soils ranged from 0.31 to $0.87 \mathrm{cmol}_{\mathrm{c}} \mathrm{kg}^{-1}$ while that of the $\mathrm{AEZ}$ 6 soils varied from 0.56 to $0.68 \mathrm{cmol}_{\mathrm{c}} \mathrm{kg}^{-1}$ (Table 6). The exchangeable sodium content for these soil series was less than that for soil series in the coastal area because of inundation by fresh water.

\section{Exchangeable potassium content}

As shown in Table 6, the exchangeable potassium content of the soils of AEZ 5 varied with soil series mainly based on the clay content: higher for the Laskara and Tarash series ( 0.14 to $0.27 \mathrm{cmol}_{\mathrm{c}} \mathrm{kg}^{-1}$ ) and lower for the Manda, Malanchi and Gangachara series (0.07 to $\left.0.11 \mathrm{cmol}_{\mathrm{c}} \mathrm{kg}^{-1}\right)$. The first group had exchangeable

Table 7. Correlation matrix between physical and chemical properties of the soils

\begin{tabular}{|c|c|c|c|c|c|c|c|c|c|c|c|}
\hline & Clay & $\mathrm{pH}$ & $\mathrm{AA}$ & CEC & $\mathrm{OM}$ & $\mathrm{N}$ & $\mathrm{P}_{1}$ & $\mathrm{P}_{2}$ & $\mathrm{~S}$ & K & $\mathrm{Ca}$ \\
\hline Clay & 1 & & & & & & & & & & \\
\hline $\mathrm{pH}$ & $-0.606^{* *}$ & 1 & & & & & & & & & \\
\hline $\mathrm{AA}$ & $0.520 *$ & $-0.831 * *$ & 1 & & & & & & & & \\
\hline CEC & $0.898 * *$ & $-0.599 * *$ & $0.563 * *$ & 1 & & & & & & & \\
\hline $\mathrm{OM}$ & $0.647^{* *}$ & -0.197 & 0.173 & $0.672 * *$ & 1 & & & & & & \\
\hline $\mathrm{N}$ & $0.689 * *$ & $-0.612^{* *}$ & $0.517^{*}$ & $0.670 * *$ & $0.652^{* *}$ & 1 & & & & & \\
\hline $\mathrm{P}_{1}$ & $-0.621^{* *}$ & $0.626^{* *}$ & $-0.507^{*}$ & $-0.593 * *$ & -0.403 & -0.403 & 1 & & & & \\
\hline $\mathrm{P}_{2}$ & $-0.679 * *$ & $0.592 * *$ & $-0.478^{*}$ & $-0.635 * *$ & -0.402 & -0.437 & $0.967 * *$ & 1 & & & \\
\hline $\mathrm{S}^{2}$ & $0.617^{* *}$ & $-0.481^{*}$ & 0.282 & $0.557^{*}$ & 0.220 & 0.375 & -0.303 & -0.311 & 1 & & \\
\hline K & $0.839 * *$ & $-0.705^{* *}$ & $0.644^{* *}$ & $0.825^{* *}$ & 0.376 & $0.631 * *$ & $-0.543^{*}$ & $-0.616^{* *}$ & $0.477^{*}$ & 1 & \\
\hline $\mathrm{Ca}$ & $0.921 * *$ & $-0.480^{*}$ & 0.437 & $0.884 * *$ & $0.592 * *$ & $0.646^{* *}$ & $-0.598 * *$ & $-0.683^{* *}$ & 0.441 & $0.838 * *$ & 1 \\
\hline $\mathrm{Mg}$ & $0.740 * *$ & -0.274 & 0.394 & $0.773 * *$ & $0.595^{* *}$ & $0.511 *$ & -0.185 & -0.216 & 0.406 & $0.650 * *$ & $0.733^{* *}$ \\
\hline
\end{tabular}

** and * mean correlation significant at the 0.01 and 0.05 levels, respectively (2-tailed).

Clay: clay percentage AA: active acidity $\quad$ CEC: cation exchange capacity OM: organic matter content N: total N content $\mathrm{P}_{1}$ : available $\mathrm{P}$ determined by the Olsen method $\quad \mathrm{P}_{2}$ : available $\mathrm{P}$ determined by the Bray and Kurtz method

S: available S content $\quad \mathrm{K}$ : exchangeable K content $\quad \mathrm{Ca}$ : exchangeable Ca content $\mathrm{Mg}$ : exchangeable Mg content 
potassium in the medium to optimum level and the second group had the low level in respect of crop production (BARC, 1997). While, the exchangeable potassium content of the soils of AEZ 6 having the higher clay content was highest ( 0.33 to $0.50 \mathrm{cmol}_{\mathrm{c}} \mathrm{kg}^{-1}$ ) to be evaluated in the high to very high level.

\section{Non-exchangeable potassium content}

The non-exchangeable potassium content of the AEZ 5 soils ranged between 4.5 and $7.7 \mathrm{cmol}_{\mathrm{c}} \mathrm{kg}^{-1}$ while that of the AEZ 6 soils ranged between 3.3 and $7.8 \mathrm{cmol}_{c}$ $\mathrm{kg}^{-1}$ (Table 6). No definite trend was found for variation among the soils. However, relatively good amounts of non-exchangeable potassium were found in all soil series.

\section{Correlation matrix}

The correlation matrix for physical and chemical properties determined in the present study is given in Table 7. It was understood that the clay content was the most fundamental property to control chemical properties of soils in AEZs 5 and 6. The clay content is most important for efficient land use and better soil and crop management in these agroecological regions.

\section{CONCLUSIONS}

The soils of AEZ 5 were mostly medium-textured and had the lower values of organic matter, lime requirement, total nitrogen, $\mathrm{CEC}$, and some exchangeable cations than did the soils of AEZ 6 which were fine-textured having the higher content of clay. Other chemical properties also varied among the soils irrespective of AEZs and soil series. Deficiencies of different nutrients were found to occur. Hence, soil fertility should be improved based on the results obtained in the present study.

\section{ACKNOWLEDGEMENTS}

We are grateful to the scientists and staffs of Soil Resource Development Institute (SRDI), Rajshahi, for helping in collection of soil samples for this study.

\section{REFERENCES}

BARC 1997 Fertilizer Recommendation Guide. Bangladesh Agricultural Research Council, Farmgate, Dhaka (Bangladesh)
Bouyoucos, G. J. 1927 The hydrometer as a method for the mechanical analysis of soils. Soil Sci., 23: 343-353

Brady, N. C. 2002 The Nature and Properties of Soils, 13th ed. McMillan, New York (USA)

Bray, R. H and L. T. Kurtz 1945 Determination of total, organic and available forms of phosphorus in soils. Soil Sci, 59: 39-45

Bremner, J. M. and C. S. Mulvaney 1982. Total nitrogen. In "Methods of Soil Analysis (Part 2)", 2nd ed., ed. by A. L. Page, R. H. Miller and D. R. Keeny, American Society of Agronomy, Inc. and Soil Science Society of America, Inc., Madison, Wisconsin, pp. 595-622

Chapman, H. D. 1965. Cation exchange capacity. In "Methods of Soil Analysis". ed. by C. A. Black, American Society of Agronomy, Inc., Madison, Wisconsin, pp. 891-901

FAO-UNDP 1988 Land Resources Appraisal of Bangladesh for Agricultural Development, Report 2, Agroecological Regions of Bangladesh. FAO, Rome (Italy), 570pp

Knudsen, D., G. A. Peterson and P. F. Pratt 1982 Lithium, sodium and potassium. In "Methods of Soil Analysis (Part 2)", 2nd ed., ed. by A. L. Page, R. H. Miller and D. R. Keeny, American Society of Agronomy, Inc. and Soil Science Society of America, Inc., Madison, Wisconsin, pp. 225-246

Marshall, T. J. 1947 Mechanical Composition of Soils in Relation to Field Description of Texture. Commonwealth of Australia, Council for Scientific and Industrial Research, Bulletin 224, Melbourne (Australia), p. 20

Nelson, D. W. and L. E. Sommers 1982 Total carbon, organic carbon and organic matter. In "Methods of Soil Analysis (Part 2)", 2nd ed., ed. by A. L. Page, R. H. Miller and D. R. Keeny, American Society of Agronomy, Inc. and Soil Science Society of America, Inc., Madison, Wisconsin, pp. 539-580

Olsen, S. R., C. V. Cole, F. S. Watanabe and L. A. Dean 1954 Estimation of Available Phosphorus in Soils by Extraction with Sodium Bicarbonate. U.S. Department of Agriculture Circ., p. 929

Portch, S. and M. S. Islam 1984 Nutrient status of some important agricultural soils of Bangladesh. In "Proceedings of the International Symposium on Soil Test Crop Response Correlation Studies", Bangladesh Agricultural Research Council and Soil Science Society of Bangladesh, Dhaka (Bangladesh), pp. 97-106

Saheed, S. M. 1984 Soils of Bangladesh. In "Proceedings of the International Symposium on Soil Test Crop Response Correlation Studies", Bangladesh Agricultural Research Council and Soil Science Society of Bangladesh, Dhaka (Bangladesh), pp. 107-129

Shoemaker, H. E., E. O. McLean and P. F. Pratt 1961 Buffer methods for determining lime requirement of soils with appreciable amounts of extractable aluminum. Proc. Soil Sci. Soc. Am., 25: 274-277

Tamhane, R. V., D. P. Motiramani, Y. P. Bali and R. L. Donahue 1970 Soils: Their Chemistry and Fertility in Tropical Asia. Prentice Hall of Indian Private Limited, New Delhi (India), p. 29

Williams, C. H. and A. Steinbergs 1959 Soil sulphur fractions as chemical indices of available sulphur in some Australian soils. Aust. J. Agric. Res., 10: 340-352 